\title{
As estratégias de sobrevivência e de busca de emprego adotadas pelos desempregados ${ }^{2}$
}

\author{
Juliana Telles de Azevedo; Marcelo Calipo Bogre; Vanessa \\ Mies Bombardi; Marcelo Clay Chen; Eduardo Yuiti Mampo; \\ Aparecida Norma Martins; Alexandre Lara de Moraes; Ana \\ Paula Oliveira e Silva e Maria de Fátima Neves da Silva
}

\section{Resumo}

\begin{abstract}
Este trabalho tem por objetivo conhecer como trabalhadores desempregados lidam com a situação de desemprego, de modo a caracterizar suas estratégias de sobrevivência e recolocação no mercado de trabalho. Parte-se do pressuposto de que estas estratégias estão orientadas pelas representações sociais destes trabalhadores a respeito da questão do desemprego. Para tanto realizou-se um estudo qualitativo em que foram entrevistados trabalhadores desempregados em duas instituições: o Sistema Nacional de Empregos de São Paulo (Sinesp) e o Sindicato dos Metalúrgicos de Osasco. A análise constituiu-se no levantamento e exploração de alguns temas básicos presentes nas entrevistas: estratégias de sobrevivência adotadas pelos trabalhadores desempregados, representação do mercado de trabalho, representação de emprego e concepção do próprio desemprego, manutenção do vínculo de trabalho, repercussão do desemprego e perspectivas de futuro. Estes temas constituíram-se objeto de análise de cada entrevista, de modo que se pudessem conhecer as formas particulares através das quais os trabalhadores lidam com estas questões. As estratégias de sobrevivência e recolocação são influenciadas pelas redes de relações que o trabalhador faz parte. Embora as estratégias atuais sejam basicamente as mesmas do passado, estas se mostram menos eficazes devido às maiores dificuldades que o mercado de trabalho tem imposto nas últimas décadas.
\end{abstract}

\section{Introdução}

Há anos vem sendo possível constatar que o crescimento do desemprego não é fruto apenas de uma crise passageira de um mercado de trabalho auto-regulável, como apontam alguns. Mattoso (1994) tem procurado entender o problema do desemprego dentro de um contexto mais amplo. Segundo este autor:

...os problemas enfrentados pelo mundo do trabalho, atualmente, são muito mais profundos e complexos do que o simples aumento do desemprego, supostamente devido ou a eventuais razões conjunturais (recessão) ou à rigidez da organização e das relações de trabalho. Na verdade, sua origem encontra-se no rompimento do padrão de desenvolvimento do pós-guerra, realizado a partir da década de 80 , cujos efeitos vêm sendo ampliados com a recente recessão econômica (p. 13).

\footnotetext{
2 Uma versão preliminar deste trabalho foi apresentado no XXVI Congresso Interamericano de Psicologia (Pontifícia Universidade Católica, São Paulo, julho de 1997) e no V Encontro Estadual de Clínicas-Escola (Universidade São Judas Tadeu, São Paulo, agosto de 1997).

3 Supervisores: Fábio de Oliveira, Leny Sato e Sandro A. Mazzio.
} 
Em seu artigo "Trabalho sob Fogo Cruzado", Mattoso procura esquematizar essas transformações do capitalismo no pós-guerra e seus efeitos sobre as relações de trabalho. Segundo sua análise, após a 2aㅡ Guerra Mundial os países avançados desfrutaram de um grande avanço tecnológico. Estabeleceu-se nestes mesmos países as normas de produção, o padrão de consumo e as relações trabalhistas baseadas nos padrões de desenvolvimento norte-americano. Esta conjuntura permitiu o crescimento do capitalismo, acompanhado de pleno emprego e fortalecimento das relações de trabalho. O padrão de desenvolvimento do pós-guerra sofreu uma ruptura a partir das décadas de 60 e 70, sendo seus efeitos sentidos muito mais intensamente nos anos 80. A Terceira Revolução Industrial (ligada ao uso mais intenso da informática) e a nova configuração do capitalismo mundial (deixando de ser eminentemente de tipo industrial para tornarse predominantemente financeiro), seriam os dois principais motivos que levaram à quebra do padrão de desenvolvimento anterior. Com isso estabeleceu-se uma nova ordem produtiva, contendo outro modelo tecnológico e novas relações entre o capital e o trabalho. Este novo padrão de desenvolvimento permitiu o surgimento de um novo modelo de trabalhador, mais qualificado, polivalente e competitivo.

Mas este novo modelo de trabalhador é apenas uma parte da história. Concomitantemente o capital financeiro (carregando a bandeira da globalização) investiu contra as relações de trabalho:

Este capital buscou reestruturar-se em nome da maior competitividade e globalização internacional, movendo-se contra o trabalho organizado. Tratou-se de um esforço concentrado de questionamento sobre uma série de direitos ou conquistas dos trabalhadores e das sociedades democráticas contemporâneas, obtida no ambiente internacional da bipolaridade, do Estado de Bem-Estar, das políticas econômicas do tipo keynesianas e do crescimento estável. Neste sentido, podemos considerar que reverteu-se o longo período de realinhamento da relação capital/trabalho e gerou-se uma crescente insegurança e desestruturação do trabalho (Mattoso, 1994: p. 14).

Os efeitos desta nova configuração mundial da relação capital/trabalho podem ser sentidos como aquilo que convencionou-se chamar "desemprego estrutural", gerando algumas conseqüências sobre a população que não consegue enquadrar-se neste novo paradigma do capitalismo:

Portanto, o surgimento daquele novo trabalhador teve como contrapartida uma crescente massa de trabalhadores que, perdendo seus antigos direitos e não se inserindo de forma competitiva, ainda que funcional, no novo paradigma tecnológico, tornou-se desempregada, marginalizada ou empregada sob novas formas de trabalho e qualificação, em relações muito precárias e nãopadronizadas. Desta forma, observou-se a maior fragmentação e heterogeneidade do mundo do trabalho, com o rompimento de diferentes formas de defesa ou de segurança do trabalho constituídas no pós-guerra (Mattoso, 1994: p. 15).

Atualmente, a dinâmica do modo de produção capitalista pode ser assim esquematizada: os altos investimentos em tecnologia para baixar os preços e melhorar a qualidade da produção necessitam de grandes lucros que possam viabilizá-los; a solução é cortar custos e operar em nível global. Procuram-se lugares no mundo onde o custo dos trabalhadores seja menor, haja menos impostos, pouca fiscalização de regimes de trabalho e meio ambiente. Sempre visando maiores lucros, as grandes empresas formam conglomerados que incorporam novos mercados. O desenvolvimento tecnológico e a automação produzem dispensa de trabalhadores. A conseqüente diminuição no custo 
das mercadorias produz um círculo vicioso no qual os menores preços possibilitam vendas maiores, novos mercados são conquistados, novas tecnologias são pesquisadas e incorporadas às empresas e os trabalhadores são dispensados para a maior redução do custo fixo de pessoal, proporcionada pela automação. Nos últimos dez anos as empresas tiveram um aumento real em seus lucros, mas o desemprego cresce sistematicamente.

A terceirização na economia, que vem aumentando nos últimos tempos, tem o intuito de reduzir custos: a grande empresa diminui seus gastos com encargos e impostos. Além disso, custos fixos tornam-se variáveis, paga-se por peça efetivamente produzida, por horas efetivamente trabalhadas. O setor terciário, que poderia ser uma possível saída para o desemprego nas indústrias, encontra-se igualmente automatizado. Perde-se, assim, a ilusão de que ele iria absorver a mão-de-obra excedente. Deste modo, tanto a automatização quanto as tendências de terceirização são irreversíveis, porque baseiam-se na sólida lógica de mercado: menores preços e maior qualidade no produto final.

Dentro deste contexto, agravou-se a situação de deterioração da distribuição de renda e aumento da pobreza. O problema não se resume, portanto, apenas e tão somente no aumento do número de vagas disponíveis no mercado. Segundo Mattoso (1994):

Trata-se, sobretudo, de repensar criativamente novas formas e mecanismos institucionais de redistribuir riqueza e tempo de trabalho, assim como revalorizar a crítica social de um sistema que, abandonado à sua lógica interna, recriaria, ainda mais intensamente, desigualdade e exclusão (p. 21).

Mattoso aponta ainda que, neste processo, a sindicalização foi perdendo sua força e coesão, assumindo uma postura mais defensiva, que expressa cada vez mais a urgência da adoção de políticas de criação e manutenção de empregos e de organização de trabalhadores desempregados.

No Brasil há uma progressiva informalização nas relações de trabalho e queda na qualidade de vínculo com o empregador. O crescente aumento do número de trabalhadores informais pode indicar uma contínua fragilização da qualidade do emprego no que se refere à remuneração, estabilidade, proteção e benefícios sociais. $\mathrm{O}$ desemprego dos jovens também é um alerta, pois mais da metade do desemprego atual está concentrado na população de até 24 anos. Outra questão importante é a efetiva participação da mulher no mercado de trabalho a partir da década de 80 , aumentando o universo daqueles que estão à procura de emprego. No caso do Brasil há ainda um grande fluxo migratório da população rural às grandes cidades, fenômeno que vem contribuir para o crescimento do número de desempregados.

Se de um lado o equacionamento do problema do desemprego, como visto acima, reclama medidas de caráter estrutural e, por isso, não necessariamente alcançáveis a curto prazo, de outro, os trabalhadores desempregados, cotidianamente têm de adotar estratégias para garantir a sobrevivência e para conseguir uma colocação no mercado de trabalho.

Perante o quadro de desemprego atual, como se dá, na prática, o encontro do trabalhador com a vaga oferecida? Quais seriam as principais estratégias utilizadas pelos desempregados nas suas tentativas de recolocação no mercado de trabalho numa situação de crescente e permanente desemprego?

Lautier e Pereira (1994) ocupam-se destas questões e no artigo "Representações Sociais e Construção do Mercado de Trabalho: Empregadas Domésticas e Operários da Construção Civil na América Latina", concluem: 
... os relatos de vida mostravam geralmente que se encontrava um emprego (na indústria, no setor público, mas também nas atividades informais) mais por meio de informações personalizadas ou de favores, ou, ainda, pela condição étnica ou política, do que pela resposta dada espontaneamente por um mercado anônimo, tal como pelos anúncios de jornais ou de outro tipo, ou, ainda, por uma agência nacional de empregos ou empresas especializadas na contratação de mão-deobra (p. 128).

Estes favores e informações personalizadas constituem aquilo que os autores denominam "rede de relações interpessoais" (ou simplesmente "rede") que, junto com o Estado e o Mercado, agiria como agente regulador da estrutura e dinamismo do mercado de trabalho e, por conseguinte, do "mercado" de desempregados. Ou seja, para se entender a fundo o mercado de trabalho, deve-se levar em conta não somente elementos econômicos e políticos (como os apontados por Mattoso), mas também aspectos representados, entre outras coisas, pela rede de relações pessoais, tanto dos trabalhadores que estão inseridos dentro deste mercado como daqueles que não conseguem participar dele (os desempregados). No atual processo de globalização, em que as influências do Estado tendem a minimizar-se, visto serem um "obstáculo" ao livre trânsito do capital, a importância das redes de relações interpessoais ganha maior relevância como instância reguladora dentro do mercado.

Pelo que foi dito, o uso das redes de relações interpessoais seria uma das estratégias adotadas pelos desempregados na sua busca de um novo emprego. Contudo, da mesma forma que o mercado de trabalho não depende, única e exclusivamente, de fatores econômicos e políticos, as estratégias de recolocação também são influenciadas por fatores subjetivos. As táticas e métodos adotados são uma confluência de vários aspectos: sociais, políticos, culturais, afetivos etc. Lautier e Pereira (1994) relatam uma história esclarecedora:

Observou-se, por exemplo, o caso de uma doméstica em Brasília que preferia morar na cidade-satélite (apesar da sua patroa lhe oferecer um alojamento bem mais confortável), o que implicava uma hora ou mais de transporte nos dois sentidos, o custo do ônibus podendo equivaler a um quarto do salário, sem contar o custo de construção da casa. O desejo de independência intervém, com certeza, numa estratégia deste tipo, mas ele se encontra muitas vezes sobredeterminado pelo fato de que dispor de sua própria casa aparece como uma condição sine qua non para manter uma relação conjugal (geralmente, com um operário da construção, também se defrontando com o problema de encontrar moradia). Da mesma maneira, as estratégias migratórias dos peões do Nordeste para São Paulo ou Rio de Janeiro podem corresponder à busca de uma qualificação profissional, tanto quanto constituir um meio de acumular um dinheiro para aumentar o tamanho da roça familiar, ou, ainda, para construir uma casa quando voltar para o Nordeste (p. 135).

Desta forma, para entender as estratégias, planos e movimentos das pessoas dentro do mercado de trabalho (e, principalmente, das que estão fora dele), faz-se necessário compreender os sistemas de representações que influenciam estas mesmas estratégias, pois são justamente elas que vão informar os modos como as pessoas vão procurar a sua reinserção no mercado de trabalho e/ou a sua sobrevivência:

A extrema diversidade dessas estratégias não se explica apenas pelas condições ditas "objetivas" (a probabilidade de encontrar tal ou tal emprego em um momento da conjuntura, ou os diversos tipos de recursos mobilizáveis). A escolha de uma estratégia repousa em um triplo sistema de representações: de si 
mesmo, da atividade de trabalho, do mercado de trabalho na sua totalidade (Lautier e Pereira, 1994: p. 136).

Esta idéia é extremamente condizente com o conceito de representações sociais. Há um jogo entre a realidade objetiva e as representações sociais, cada uma delas influenciando a outra. Spink (1994) trata desta questão e, baseada em Jodelet, afirma:

... as representações sociais devem ser estudadas articulando elementos afetivos, mentais, sociais, integrando a cognição, a linguagem e a comunicação às relações sociais que afetam as representações sociais e a realidade material, social e ideativa sobre a qual elas intervém (p. 121).

Assim, as representações sociais, como uma forma de conhecimento prático, orientam as ações das pessoas sobre o contexto e a realidade em que estão inseridas. Desta forma, para se conhecer as ações práticas (as estratégias) dos desempregados que buscam se reinserir no mercado de trabalho, é preciso compreender as representações sociais sobre o mundo do trabalho (concepções sobre o mercado, sobre emprego, sobre o futuro etc.).

O objetivo deste trabalho é descobrir as estratégias de recolocação profissional adotadas pelos trabalhadores que se encontram desempregados, bem como suas estratégias de sobrevivência, quando a reinserção no mercado de trabalho encontra-se impedida. Para tanto, buscou-se conhecer e entender as representações sociais sobre o mundo do trabalho do grupo de desempregados pesquisados.

\section{Metodologia}

A fim de obter um melhor acesso às representações sociais relacionadas ao mundo do trabalho, optou-se por uma pesquisa qualitativa, através de entrevistas pessoais semidirigidas, conforme um roteiro previamente testado e estabelecido. Desta forma o número de sujeitos, ainda que reduzido, possibilitou um maior aprofundamento do histórico pessoal e profissional dos entrevistados e de suas representações. Através de seus relatos, pode-se refletir sobre as trajetórias de outros trabalhadores inseridos no mesmo contexto social, pois as histórias dos entrevistados ilustram a vida de milhares de outros desempregados. Espera-se que no futuro este trabalho possa servir de base para uma pesquisa mais ampla e completa, onde também dados populacionais possam ser contemplados. Esta proposta epistemológica vai ao encontro da conceituação proposta por Spink no texto "Desvendando as teorias implícitas: uma metodologia de análise das representações sociais":

Não é um indivíduo isolado que é tomado em consideração, mas sim as respostas individuais enquanto manifestações de tendências do grupo de pertença ou de filiação no qual os indivíduos participam (1994: p. 120).

a) População estudada: para a realização deste trabalho foram entrevistados 17 trabalhadores desempregados. As entrevistas foram gravadas mediante a permissão dos entrevistados e posteriormente transcritas e analisadas. As entrevistas cuja gravação não foi autorizada foram registradas pelo entrevistador de forma a preservar, na medida do possível, todas as informações oferecidas pelo entrevistado. As entrevistas foram 
realizadas em local reservado, apenas com a presença do pesquisador e da pessoa entrevistada.

Como critério para a seleção dos sujeitos foi utilizado o registro profissional na carteira de trabalho, ou seja, foram entrevistadas apenas pessoas que já tivessem, em sua carteira profissional, algum emprego registrado. Com este procedimento tentou-se evitar que fossem entrevistadas pessoas à procura do primeiro emprego e cujas estratégias de recolocação poderiam diferir das estratégias de trabalhadores com algum registro em carteira.

Outros critérios foram adotados para as entrevistas: idade, variando de 20 a 45 anos (faixa etária considerada de atividade produtiva e com pouca perspectiva de aposentadoria a curto ou médio prazo); distinção por sexo, a fim de observar se havia relação entre sexo e estratégias de sobrevivência e recolocação no mercado adotadas; escolaridade até $2 \underline{0}$ grau completo.

Para fins de análise foi realizada uma distinção entre trabalhadores "operacionais" e trabalhadores "não operacionais", categorização adotada pelo Sinesp (Sistema Nacional de Empregos dos Estado de São Paulo). Segundo tal categorização, são trabalhadores operacionais aqueles que exercem profissões que não exigem uma alta qualificação ou escolaridade (geralmente são trabalhadores que concluíram até a $4^{a}$ série), executando funções que envolvem grande esforço físico e/ou intensa repetição de movimentos - ajudantes gerais e empacotadores, por exemplo; são trabalhadores não operacionais aqueles que exercem profissões que necessitam de maior nível de escolarização (pelo menos o $1^{\circ}$ grau completo) e alguma qualificação (geralmente algum curso profissionalizante), e recebem remuneração salarial superior à de trabalhadores operacionais - torneiros mecânicos e técnicos eletrônicos, por exemplo. A divisão entre trabalhadores operacionais e não operacionais foi adotada na pesquisa como uma forma de verificar possíveis diferenças nas estratégias utilizadas, dependendo da qualificação profissional do desempregado. Como padronização para as entrevistas, a categoria profissional (trabalhador operacional ou não operacional) era definida pelo último registro na carteira de trabalho, não importando os registros anteriores. Se, por exemplo, o último emprego de um entrevistado foi empacotador, ele foi inserido no contingente de trabalhadores operacionais. Durante a análise dos resultados discutir-se-á a mudança entre profissões operacionais e não operacionais, presente ao longo da trajetória profissional dos trabalhadores.

b) Instrumento de coletas de dados: conforme citado anteriormente, as entrevistas eram semidirigidas, baseadas em um roteiro. Inicialmente foi elaborado um primeiro roteiro, com perguntas que pudessem esclarecer sobre a trajetória profissional do trabalhador, suas representações e concepções sobre o mundo do trabalho, bem como informações adicionais relevantes (estado civil, escolaridade, local de nascimento etc.). Este roteiro inicial foi testado nos dois locais a serem utilizados para a pesquisa. Após a análise destas "entrevistas-piloto", o roteiro sofreu pequenos ajustes para, enfim, ser utilizado de forma definitiva no trabalho de campo. O anexo 1 contém o roteiro final para as entrevistas.

c) Locais de acesso à população: a pesquisa foi realizada em duas instituições, cujas especificidades de atendimento correspondiam ao tipo de trabalhador procurado: no Sistema Nacional de Empregos de São Paulo (Sinesp) e no Sindicato dos Metalúrgicos de Osasco e Região. A seguir, apresenta-se uma pequena descrição destas instituições e suas principais atividades, bem como os procedimentos utilizados para a realização das entrevistas em ambos os locais.

Sinesp: o Sinesp (Sistema Nacional de Empregos do Estado de São Paulo) é uma instituição pública mantida pelo Ministério do Trabalho, pelo FAT (Fundo de Amparo 
ao Trabalhador) e pelo Estado de São Paulo. Em termos gerais, pode-se dizer que o Sinesp funciona como uma agência de empregos, sendo financiada com recursos públicos, ao invés de particulares. Esta instituição possui três balcões principais para o atendimento aos desempregados: um deles cuida exclusivamente das pessoas que possuam escolaridade superior; os outros dois são responsáveis pelo atendimento dos demais desempregados: o primeiro cuida das pessoas que estão procurando o Sinesp pela primeira vez e o segundo é destinado ao atendimento dos desempregados que procuraram a instituição outras vezes e já estão cadastrados. O Sinesp também providencia carteiras profissionais e cuida dos requerimentos para o seguro-desemprego.

Além do atendimento ao público, a instituição possui um setor responsável por captar vagas disponíveis no mercado de trabalho. Através de contato telefônico, o Sinesp procura empresas que estejam contratando e que queiram oferecer as suas vagas disponíveis para o uso do serviço. Apenas pessoas jurídicas (indústrias e comércios) podem oferecer empregos; pessoas físicas não podem oferecer vagas (para babá ou doméstica, por exemplo). Em média são contatadas seis mil empresas por semana, o que proporciona em torno de três mil vagas para a instituição (dados do $1^{\varrho}$ semestre de 1996).

Para uma melhor compreensão do funcionamento do Sinesp, vejamos o exemplo de um trabalhador desempregado e sem nível superior de escolaridade, que vai procurálo pela primeira vez. O prédio do Sinesp abre suas portas às 8 horas e é comum neste horário haver grandes filas de trabalhadores que serão atendidos pelo serviço. $\mathrm{O}$ vigia é responsável por recolher as carteiras de trabalho das pessoas que estão na fila, separá-las conforme o balcão para o qual as pessoas deverão dirigir-se e colocá-las em ordem de chegada. No caso do trabalhador estar procurando o Sinesp pela primeira vez, a carteira será colocada junto à de outros desempregados que estão na mesma situação. Neste balcão existem vários atendentes, cada um com um terminal de computador ligado em rede com os demais. As pessoas, chamadas pela ordem de chegada, passam por uma pequena entrevista com o atendente (nunca superando os 20 minutos). Nesta entrevista o atendente colherá algumas informações (nome, idade, experiência profissional, cursos de especialização etc.) que serão colocadas no cadastro geral de trabalhadores do Sinesp. De posse destes dados, o atendente procura saber que tipo de emprego a pessoa está procurando e consulta as vagas disponíveis. Caso ele encontre uma vaga que seja compatível com a experiência e capacidades do trabalhador, o Sinesp emite uma carta, onde constam o nome e endereço da empresa, bem como o dia e a hora em que o trabalhador deve procurá-la. É importante entender que esta carta não quer dizer que a pessoa será empregada; a seleção das vagas é sempre de responsabilidade da empresa e, no caso, os desempregados encaminhados pelo Sinesp concorrerão à vaga com outros trabalhadores que chegaram à empresa solicitante por outras vias. Se o atendente não encontrar nenhuma vaga que seja compatível com o entrevistado, a pessoa é convidada a voltar ao Sinesp em outra oportunidade. A instituição não telefona ou envia cartas avisando as pessoas sobre a abertura de uma vaga; a única forma do desempregado ter esta informação é voltando ao Sinesp.

No caso do trabalhador decidir voltar ao Sinesp (porque não havia vagas, porque não foi contratado da última vez ou, simplesmente, porque ficou novamente desempregado), ele é encaminhado ao segundo balcão, destinado às pessoas que já estão cadastradas pelo serviço. Nesta situação, o atendente chama o desempregado (sempre pela ordem de chegada) e acessa seu cadastro. É realizada uma nova entrevista, mais curta, visando apenas atualizar as informações do cadastro. $O$ atendente procura uma vaga que seja compatível com a experiência/qualificação do trabalhador e, caso esta seja encontrada, será emitida a carta com o nome e endereço da empresa. Não havendo 
vagas disponíveis no momento, o trabalhador é convidado novamente a voltar em outra ocasião.

A divisão do atendimento em dois balcões, um para pessoas que procuram a instituição pela primeira vez (cujo atendimento é mais demorado) e outro para pessoas que já possuem cadastro, justifica-se pelo grande número de desempregados sem nível superior que procura o Sinesp.

O balcão destinado a pessoas com nível universitário possui um atendimento que condensa o trabalho dos outros dois (não há diferenciação entre trabalhadores cadastrados e não cadastrados), visto que o número de pessoas nesta condição é bem menor.

Sempre que é feito o encaminhamento de um trabalhador para uma vaga, o Sinesp entra em contato com a respectiva empresa a fim de informar-se sobre a efetivação ou não do contrato e, neste caso, sobre o motivo da não efetivação. Assim procura-se melhorar a qualidade do serviço prestado pela instituição.

Em média, são enviados quatro trabalhadores para cada vaga disponível. O Sinesp atende de 400 a 800 desempregados por dia (segunda e terça-feira são os dias da semana em que a procura pelo serviço é maior) e, em média, 72 mil pessoas por ano (dados do $1^{o}$ semestre de 1996). A grande maioria dos trabalhadores que procura o Sinesp possui profissões de nível operacional.

Para realizar as entrevistas no Sinesp foram selecionados trabalhadores que procuravam a instituição pela primeira vez. Esses trabalhadores geralmente tinham que aguardar algumas horas até serem atendidos (geralmente a manhã toda), e nesse período de espera eram realizadas as entrevistas. Dentre aqueles que haviam chegado por último, escolhia-se um, através da carteira de trabalho, verificando-se se o sujeito encaixava-se nos critérios propostos para as entrevistas (sexo, idade, escolaridade e categoria profissional). $\mathrm{O}$ dono da respectiva carteira profissional era chamado e convidado a participar da pesquisa, sendo-lhe explicado o motivo da conversa e garantindo-se o anonimato e o sigilo das informações fornecidas. A ordem do atendimento era assegurada ao trabalhador. $\mathrm{O}$ tempo de duração de cada conversa era variável, de modo que pudéssemos obter o esclarecimento dos temas propostos no roteiro (em média as entrevistas duravam em torno de 50 minutos e não chegavam a ultrapassar uma hora de duração). Terminada a entrevista, a pessoa voltava para a fila até o momento de ser atendida pelo funcionário do Sinesp.

Sindicato dos Metalúrgicos de Osasco e Região: o Sindicato possui diversos compromissos e preocupações com os trabalhadores que atende. Entre eles estão a fiscalização do registro em carteira, o depósito do fundo de garantia dos trabalhadores, os problemas decorrentes de acidentes de trabalho e o pagamento do que é devido ao trabalhador quando este é dispensado. Uma das questões que tem ocupado os sindicalistas ultimamente é a transferência de algumas empresas de Osasco para outras regiões do país. Entre os motivos destas transferências estão as isenções fiscais e tributárias, e, basicamente, a ocupação de locais onde a fiscalização da saúde do trabalhador é inoperante e o sindicalismo não se mostra tão forte e organizado.

Um dos principais serviços prestados pelo Sindicato é a assistência jurídica aos trabalhadores. Esta assistência pode se dar em um plantão jurídico que ocorre em alguns dias e horários específicos, onde advogados do Sindicato tiram as dúvidas de alguns trabalhadores sobre processos trabalhistas. Geralmente são pessoas que sofreram algum acidente de trabalho e precisam entrar com uma ação na Previdência para conseguir a 
aposentadoria por invalidez. Neste caso, os advogados responsabilizam-se pelo processo enquanto este estiver em julgamento.

Além disso, os advogados do Sindicato também prestam assistência no momento da homologação do contrato de trabalho, ou seja, quando há o rompimento formal do contrato de trabalho, após o trabalhador é demitido. É neste momento que a empresa paga todos os direitos do trabalhador (salários atrasados, FGTS, férias etc.). A homologação acontece no próprio Sindicato (com dia e hora marcados antecipadamente), na presença de um representante da empresa, do trabalhador dispensado e de um advogado da instituição. O advogado confere todos os cálculos feitos pela empresa para o reembolso do desempregado; caso esteja tudo certo, a homologação é assinada. Se os cálculos não estiverem corretos, o advogado orienta o trabalhador a não assinar a homologação para que ele possa mover um processo contra a empresa por débitos não pagos. Neste caso, o advogado sugere que o desempregado entre com uma ação contra a empresa, processo este que é acompanhado pelo Sindicato.

Para a realização das entrevistas neste local procedeu-se da seguinte forma: momentos antes da homologação, as carteiras de trabalho dos desempregados ficavam à disposição do Sindicato para o cálculo de seus direitos. Dentre estas carteiras verificavase quais pessoas estavam dentro dos critérios para a pesquisa (sexo, idade, escolaridade e categoria profissional); quando uma delas terminava a sua homologação, era abordada pelo entrevistador que explicava os motivos da pesquisa e garantia o sigilo das informações fornecidas; caso o trabalhador concordasse em participar, era levado para uma sala, onde a entrevista era conduzida sem interrupções. Da mesma forma que no Sinesp, o tempo das entrevistas era variável. Em média cada entrevista durava em torno de 50 minutos, nunca ultrapassando mais de uma hora de duração.

d) Análise dos dados: Tendo como um dos objetivos conhecer as representações sociais sobre o mundo do trabalho, optou-se pela análise dos discursos dos desempregados como forma de avaliação dos resultados. As falas dos trabalhadores foram divididas em alguns temas principais. Alguns destes temas foram previamente selecionados pelos pesquisadores para compor o roteiro, (estratégias utilizadas para recolocação no mercado de trabalho, conceito de emprego etc.). Durante a primeira leitura das entrevistas, percebeu-se no discurso dos trabalhadores a presença de outros temas relevantes, não contemplados no roteiro (entre eles, concepções sobre o próprio desemprego). Os temas selecionados para análise foram os seguintes: Estratégias de Sobrevivência e Recolocação no Mercado; Representações do Mercado de Trabalho; Representações de Emprego; Concepções do Próprio Desemprego; Perspectivas de Futuro; Rompimento do Vínculo de Trabalho. Estabelecidas essas categorias de análise de forma definitiva, procedeu-se a uma nova leitura das entrevistas, com o objetivo de identificar, em cada uma delas, fragmentos que se referissem a cada um daqueles temas. Separou-se os trechos de cada entrevista, agrupando-os aos seus temas correspondentes. Desta forma, cada uma das categorias foi analisada em termos de conteúdo, buscando-se relações entre homens/mulheres - trabalhadores operacionais/não operacionais e estabelecendo-se hipóteses relacionadas aos perfis característicos de cada tema, bem como a relação entre eles. 


\section{Resultados}

\section{Estratégias de Sobrevivência e de Recolocação no Mercado:}

Este tema englobou as principais formas pelas quais as pessoas entrevistadas garantem sua sobrevivência (fontes de renda principais e alternativas ou qualquer outro modo de sustento) e sua recolocação no mercado de trabalho (formal ou informal).

O principal modo de sobrevivência dos entrevistados está diretamente relacionado à sua participação no mercado de trabalho, visto que se constitui em sua fundamental, senão única, garantia de sobrevivência. É, portanto, intrínseca a relação entre modos de sobrevivência e inserção no mercado de trabalho. Em uma tentativa de discriminá-los estabeleceu-se que seriam consideradas "Estratégias de Recolocação no Mercado" as táticas, direta ou indiretamente adotadas, que visariam a uma reinserção no mercado de trabalho, enquanto as "Estratégias de Sobrevivência" seriam aquelas relacionadas à garantia de necessidades básicas (principalmente alimentação e moradia), usadas quando o acesso ao mercado de trabalho está impedido ou muito dificultado.

O que nesta pesquisa está sendo nomeado como "Mercado" inclui o que normalmente se entende como mercado de trabalho formal. Embora os mercados de trabalho formal e informal tenham se aproximado muito nos últimos anos, ainda há uma grande valorização do mercado formal, pois é justamente a ele que os desempregados tentam voltar através de suas estratégias.

As "Estratégias de Sobrevivência e Recolocação no Mercado" foram diferenciadas em relação ao período em que se deram: estratégias utilizadas atualmente e estratégias utilizadas no passado ${ }^{4}$ (em outros períodos de desemprego). O objetivo foi verificar se houve alguma alteração nas táticas escolhidas devido à intensificação do problema do desemprego.

Em se tratando das estratégias de recolocação no mercado, todos os sujeitos pesquisados demonstraram possuir uma certa "desesperança" que estava associada à ineficiência das táticas utilizadas. Apesar de os entrevistados geralmente adotarem mais de uma forma de buscar recolocação, eles reconheciam que nenhuma delas mostrava-se eficaz:

... eu já distribui uns... 140 currículos, mais ou menos. Ficha, eu já fiz mais de 60.

Tô até pensando em colocar no rádio, agora tô pensando em colocar anúncio no rádio prá ver se eu consigo alguma coisa (homem, 34 anos, operacional).

Normalmente, ou o entrevistado estava desempregado há vários meses, ou citava alguns conhecidos que estavam nesta situação, o que vai ao encontro desta "desesperança" notada nos discursos.

Nas falas dos homens não operacionais sobre suas estratégias de recolocação no mercado havia referências às várias estratégias para tentarem uma recolocação, mas suas palavras refletiam menos desespero que os demais trabalhadores. É interessante pensar este dado associado a outra informação colhida na pesquisa: dentre todas as pessoas entrevistadas, apenas os homens não operacionais relataram a possibilidade de tornarem-se autônomos (terem o seu próprio negócio) como um de seus planos para o futuro. Algumas hipóteses podem permitir a compreensão de tais observações: os homens não operacionais eram um pouco melhor remunerados que as outras categorias

4 O termo "passado" não diz respeito a um período definido de tempo (cinco ou dez anos, por exemplo), mas a vivências anteriores de situações de desemprego. 
de trabalhadores entrevistados (mulheres operacionais/ não operacionais e homens operacionais), tendo uma certa "reserva" financeira, que os outros não possuíam, ou, se possuíam, era em quantidade muito menor, devido a economias, rescisão de contrato e até ao salário da esposa quando o entrevistado era casado. Se o mercado de trabalho está "horrível", sendo muito remotas as possibilidades de uma boa recolocação, ser o "próprio patrão" torna-se uma alternativa de estratégia de sobrevivência que pode renovar as esperanças.

Já no discurso dos trabalhadores operacionais (tanto homens, como mulheres) a "reserva", quando existia, era empregada na garantia de necessidades básicas do próprio trabalhador e de seus familiares:

Então, se a pessoa não tem fundo de reserva, se não tem uma mulher que ajuda na situação em casa... você tem dois, três filhos, meu Deus! Eu não sei o que vai ser dele. Fica difícil as coisas... (homem, 34 anos, operacional).

Tal situação deve-se, possivelmente, a pouca possibilidade de se estabelecer um fundo de reserva, dados os baixos salários, e ao fato do desemprego estar sendo vivido de forma muito mais intensa por trabalhadores com essa qualificação, devido a pouca especialização de suas funções.

Aqui faz-se necessário uma distinção importante: tornar-se "autônomo" pode ter um sentido diferente, dependendo da categoria profissional e da "reserva" financeira disponível. Quando um trabalhador (homem ou mulher) não operacional manifesta um desejo de tornar-se autônomo, isto significa possuir um negócio legalizado e minimamente estruturado (uma microempresa ou um pequeno comércio, por exemplo). A intenção de ter este negócio é garantir a sobrevivência, progredir financeiramente e não mais voltar a trabalhar como empregado. Já os trabalhadores operacionais têm uma concepção um pouco diferente sobre trabalho "autônomo": tornar-se autônomo significa montar um microcomércio não legalizado e informal ("barraquinha" de cachorroquente, por exemplo). O propósito e o sentido neste caso são totalmente diferentes: a intenção é garantir minimamente a sobrevivência, sem que isto signifique um progresso profissional ou financeiro. A "barraquinha" é uma alternativa "forçada" para aqueles que não conseguem uma recolocação, e o desejo permanece sendo o de voltar ao mercado de trabalho formal e legalizado. É interessante notar que os possíveis negócios dos trabalhadores (tanto operacionais como não operacionais) surgem a partir das conversas com seus familiares e amigos, muito mais do que através de uma análise da economia ou do mercado consumidor.

Outra informação que pode ajudar a entender o problema da recolocação está no tipo de função/profissão buscada no mercado (principalmente tratando-se de trabalho em empresas). Os trabalhadores operacionais, tanto homens como mulheres, aceitam qualquer tipo de emprego que possam garantir a sobrevivência, embora haja preferências sobre a função a exercer:

O que mais gostei de fazer era trabalhar com montagem em metalúrgica e eu queria fazer isso, mas faço qualquer coisa, faxina, limpeza, costura... (mulher, 41 anos, operacional).

Já os trabalhadores não operacionais, tanto homens quanto mulheres, têm uma procura mais específica, às vezes aceitando funções próximas ou correlatas a atividades já exercidas por eles: 
Eu estou procurando emprego para a mesma função devido a minha experiência na área [secretária de escola], mas pode ser como atendente ou operadora de telemarketing. Eu gostaria de trabalhar como digitadora. (mulher, 26 anos, não operacional).

Uma hipótese que possibilitaria compreender o motivo desta escolha de funções pode estar associada ao percurso profissional do trabalhador e ao grau de qualificação exigido: ao levantar-se o histórico profissional dos trabalhadores operacionais verificouse que cada um deles exerceu funções de diversos tipos (como, por exemplo, "pedreiro", "operador de máquina", "ajudante geral") em empresas de vários ramos de atividades (construtoras, frigoríficos, materiais elétricos). Geralmente estas funções tinham em comum o fato de envolverem trabalho físico intenso e/ou repetitivo, além da baixa qualificação ou treinamento necessário para sua execução. Assim, pode-se dizer que o trabalhador operacional é mais flexível ao tentar sua recolocação: pouco qualificado, dispõe-se a exercer qualquer função para garantir sua sobrevivência e de sua família. Já o trabalhador não operacional, que possui uma qualificação um pouco melhor (na maioria das vezes um grau de escolaridade mais elevado e alguns cursos profissionalizantes), está associado a um setor mais delimitado dentro de diferentes empresas (como, por exemplo, o setor financeiro, administrativo ou de pessoal). Desta forma, o trabalhador não operacional teria uma procura um pouco mais definida e específica na sua tentativa de recolocação.

No entanto, se existem estes tipos de tendências, também verifica-se que homens e mulheres, trabalhadores operacionais e não operacionais, não conseguem obter emprego nas funções de sua preferência porque não têm a qualificação necessária, porque não há vagas disponíveis ou por qualquer outro tipo de empecilho:

Empregos para ajudantes gerais não se encontram no jornal... (mulher, 24 anos, operacional).

Eu gostaria de trabalhar em vendas porque sempre vai haver emprego nesta área, em marketing... ou entrar na área de computação gráfica, mas tem o problema da qualificação. (homem, 33 anos, não operacional).

A dificuldade para se conseguir emprego em funções da preferência do trabalhador está diretamente relacionada às exigências requeridas na busca de recolocação. Esta questão será aprofundada na análise das "Representações do Mercado".

Dentre as estratégias de recolocação no mercado usadas atualmente, encontram-se: consulta a jornais, ao Sinesp, a agências de emprego, ida à porta de empresas, atenção a placas de "precisa-se" e, principalmente, tal como emergiu no discurso dos entrevistados, o uso da rede de relações interpessoais como maneira de conseguir informações. Tanto homens quanto mulheres, operacionais ou não operacionais, relataram que conversavam com parentes e conhecidos em busca de auxílio, fosse para obter indicações diretas, fosse para obter informações que indiretamente levassem ao emprego:

Outra forma que possuo de procurar emprego é perguntando para colegas (mulher, 23 anos, não operacional). 
Foi meu pai, ele sempre passa aqui [Sinesp], e então ele me aconselhou a fazer ficha aqui. Inclusive, a recepcionista de onde ele trabalha parece que veio daqui. (homem, 28 anos, não operacional).

Ainda tratando-se das estratégias de recolocação no mercado utilizadas hoje em dia, é interessante notar que apenas as mulheres (operacionais ou não operacionais) fizeram menção à palavra "bico". Somente elas relataram que atualmente estão fazendo ou procurando alguns "bicos" para sobreviver. Comparando-se as estratégias de recolocação atuais com as usadas no passado, os homens operacionais também narraram já terem feito alguns "bicos". Desta forma, só os homens não operacionais é que não teriam feito este tipo de atividade como estratégia de sobrevivência ou de recolocação, seja no passado ou atualmente. Independentemente do que os entrevistados concebiam como "bico" e sua diferenciação de "emprego", esta concepção parecia relacionada às mesmas hipóteses que explicariam o motivo de homens não operacionais terem como alternativa tornarem-se autônomos e à sua escolha na busca para uma recolocação no mercado. A própria identidade profissional do trabalhador operacional, bem como a necessidade de um complemento de renda para garantia de sobrevivência, facilitaria que ele trabalhasse em alguns "bicos":

Paralelo ao serviço público, né, eu fiz bico de segurança, motorista de taxi de frota, isso pegando só em paralelo, só prá cobrir né... as despesas. (homem, 45 anos, operacional).

Comparando-se as estratégias de recolocação usadas nos dias de hoje com as de antigamente, dois pontos se destacam. Em primeiro lugar, todos os entrevistados relataram ter sido muito mais fácil conseguir emprego em tempos passados (na época dos primeiros empregos de cada um) do que nos dias atuais. Acrescenta-se a isto que o período de espera entre dois empregos era bem menor, isto quando a pessoa não saía de um emprego porque havia encontrado outro melhor. Algumas frases podem ser destacadas para ilustrar esta questão, como a de uma entrevistada de 24 anos e operacional que disse que antigamente, se não gostasse do novo emprego, abandonava-o e arrumava outro trabalho no mesmo dia, sem maiores dificuldades, mas que hoje em dia isto não é mais possível. Mais um exemplo:

Ele fala que, quando ficou desempregado nas vezes anteriores, era muito mais fácil para procurar emprego e a situação não era tão ruim. (homem, 33 anos, não operacional).

Verificou-se também que as estratégias de recolocação usadas antigamente eram semelhantes às usadas atualmente, com uma exceção: o uso do currículo. Foi muito raro algum trabalhador citar que na época de seus primeiros empregos tenha procurado recolocação profissional com o seu currículo (seja para resposta a anúncio de jornal, seja para levar diretamente à empresa ou qualquer outra estratégia de busca de emprego). Atualmente quase todos fazem uso do currículo como auxiliar nas suas estratégias de recolocação.

Estes dois dados revelados pela análise das estratégias atuais e passadas parecem relacionados: tem-se a impressão de que antigamente a procura por emprego era mais "informal", o número de vagas por trabalhador era maior, as exigências menores e as estratégias adotadas na busca de emprego eram mais eficazes. Atualmente, com o número de vagas por trabalhador diminuindo e as exigências do mercado aumentando, a procura por emprego tornou-se mais "profissional", isto é, o trabalhador é como um produto que tem que mostrar as suas qualidades (e de preferência que tenha mais 
qualidades que os outros). Não por acaso os principais jornais com publicações sobre emprego incluíram recentemente seções onde comentam e dão "dicas" sobre currículos. De uma forma geral, esta comparação entre as estratégias atuais e passadas de recolocação aponta para as "Representações do Mercado" que serão discutidas a seguir.

Em relação às estratégias de sobrevivência utilizadas atualmente, percebe-se que todos os entrevistados contam com a ajuda de conhecidos e/ou familiares para ajudar no seu sustento:

E agora que eu fui operada as minhas colegas me ajudaram bastante... (mulher, 41 anos, operacional).

Também foi comum a todos o uso da rescisão de contrato e do segurodesemprego como estratégia de sobrevivência:

Até trabalhar novamente, pretende garantir seu sustento através das parcelas que deve receber segundo o acordo. (homem, 23 anos, não operacional).

Em relação às estratégias de sobrevivência atuais, dois aspectos se destacam. $\mathrm{O}$ primeiro deles: os homens (operacionais ou não) citaram o salário das esposas como uma forma de sustento:

Minha esposa trabalha, né... Ela dá uma ajuda financeira. (homem, 34 anos, operacional).

As mulheres (quando casadas) não citaram os salários dos maridos como estratégia de sobrevivência. Ao que parece, o trabalho da esposa é visto como uma forma de obter-se um acréscimo ou uma renda extra para a família e não como uma realização profissional ou pessoal.

O segundo aspecto envolve as mulheres (operacionais ou não): foram as únicas a citarem como estratégia abandonar um pouco de seu "luxo pessoal":

Tem que cortar despesa. Minha unha, faz mais de um mês que não faço. (mulher, 40 anos, não operacional).

A ajuda de familiares ou conhecidos no momento do desemprego foi citada tanto como estratégia de sobrevivência passada como estratégia atual:

Graças a Deus sempre tive amizade e prá comer, as vizinhas mais íntimas trazia um pouco de cada e falava com os colegas delas para trazer, também o seu irmão não podia ajudar nisso... (mulher, 41 anos, operacional).

A recorrência a pessoas próximas não está relacionada apenas ao auxílio na satisfação de necessidades básicas. Parece relacionar-se também ao uso da rede como estratégia de recolocação no mercado: não só ajudam-se mutuamente, na medida do possível, como também trocam informações sobre emprego. Quem pode mais ajuda mais, quem pode menos ajuda menos.

O seguro-desemprego também constitui-se uma estratégia de sobrevivência nos dias de hoje. Não houve referências ao seu uso no passado pelas pessoas entrevistadas, mesmo porque este é um recurso recente na legislação trabalhista. 


\section{Representações do Mercado de Trabalho:}

Através do tema "Representações do Mercado de Trabalho" procurou-se verificar as concepções dos entrevistados a respeito do mercado de trabalho, assim como as dificuldades, exigências, preocupações e demais características que puderam perceber ou relatar em sua tentativa de reinserção dentro deste mercado. As "Representações do Mercado de Trabalho" apresentaram-se bastante relacionadas às "Estratégias de Sobrevivência e Recolocação no Mercado", pois as representações sociais são o conhecimento prático e orientam a ação das pessoas no dia-a-dia. Desta forma, as representações sociais do mercado de trabalho ajudam a planificar as estratégias de sobrevivência e de recolocação adotadas pelos trabalhadores.

De uma maneira bastante constante as colocações de todos os entrevistados giraram em torno de alguns pontos comuns. Quais sejam:

Exigências do mercado de trabalho: esse foi o ponto de convergência de todos os entrevistados. Todos se referiram às várias exigências (dentre as principais, a qualificação/escolarização, a experiência em carteira e a idade) como um dos maiores obstáculos na procura de novos empregos;

Comparações entre situação atual e passada: muitos dos entrevistados compararam sua atual condição de desemprego com a de períodos passados, estes sempre menos penosos.

A exigência de qualificação e escolaridade apareceu na fala de praticamente todos os trabalhadores. Um homem de 33 anos e não operacional comentou sobre a exigência absurda de fluência no idioma japonês para uma vaga de motorista que ele estava postulando. Em outro exemplo:

Pedem, nossa! Pelo serviço, às vezes, não precisa tanto, né, escolaridade. Por quê? Até hoje, para ser gari precisa até a quinta série, prá quê? Prá varrer rua... Não precisa, é incrivel! (homem, 32 anos, operacional).

Devido à situação atual de desemprego, a qualificação/escolaridade tornou-se fator de concorrência, mas não de salários justos ou melhor remuneração:

Porque uma pessoa que tem uma universidade, tá concorrendo por um salário de 400, 500 reais, que é baixo até para mim, que tenho segundo grau, eu acho muito baixo, e eu tô concorrendo com essas pessoas. (...) As pessoas estão contratando gente que já é administrador para trabalhar como auxiliar. Do jeito que tá as coisas a pessoa tem que se sujeitar a isso na esperança de subir de cargo dentro da empresa. (homem, 28 anos, não operacional).

Com o grande número de candidatos para cada vaga de emprego anunciada, tornou-se necessária uma alta qualificação para ser um bom concorrente. Por outro lado, o grande número de candidatos impede que se exija melhores salários, já que sempre haverá a possibilidade de algum candidato aceitar o cargo por uma baixa remuneração.

A experiência no cargo, exigida pela maioria dos empregadores, está, na maioria das vezes, submetida à comprovação na carteira de trabalho:

...eles pedem experiência. Apesar de já ter trabalhado, não consideram por não ter registro. (mulher, 23 anos, não operacional). 
O ruim de procurar emprego é que eles exigem experiência em carteira. Não interessa se você sabe, tem que estar registrado em carteira. (mulher, 38 anos, operacional).

Registro é de menos, eu não sabia mexer em elevador, em 15 dias aprendi. Vai do esforço da pessoa. Quando eu trabalhava na fábrica de xampu, eu não sabia fazer, mas de olhar, de perguntar, até xampu eu fiz. Mas eles não levam isso em consideração, é o que está na carteira. (mulher, 38 anos, operacional).

Vê-se que a necessidade de ter a carteira assinada muitas vezes sobrepõe-se à importância da experiência realmente adquirida. Ainda que o trabalhador saiba exercer com qualidade sua profissão, tal experiência é desconsiderada se não estiver comprovada em carteira.

Outra exigência importante mencionada por vários trabalhadores, principalmente mulheres, foi a idade:

Saí do emprego, né... e agora tá difícil. Deve ser... um pouco por causa... um pouco... eu tô desconfiada, que é por causa da idade, né. O pessoal já começa a bloquear, sabe, por causa da idade. (mulher, 40 anos, não operacional).

As exigências em relação à idade fazem com que, algumas vezes, pessoas com 30 anos sejam descartadas como concorrentes para determinadas funções. $O$ fato de o trabalhador exceder a idade requerida pela vaga implica em que seja, muitas vezes, cortado do processo seletivo, independentemente de sua experiência e capacidades pessoais. Por um lado, tal situação corresponde ao tratamento dado aos idosos em nossa sociedade: são constantemente desmerecidos e colocados à margem. Por outro lado, tal exigência segue as tendências do mercado globalizado, no qual impera a regra da maior produção com menores custos a fim de aumentar a margem de lucro. A maior produção seria garantida pela contratação de trabalhadores jovens que teriam maior capacidade física (devido à idade) para trabalhos que envolvem esforço muscular e tarefas repetitivas (como nas categorias profissionais aqui pesquisadas) e que, por não terem tanta experiência profissional, se sujeitariam a receber menores salários, permitindo a redução de custos. A medida que os anos vão chegando, o corpo físico vai perdendo as suas capacidades, o que torna o trabalhador idoso mais desinteressante. Talvez a melhor analogia para esta situação seja comparar o trabalhador com uma máquina: na medida que vai ficando mais velha já não produz tanto, gasta-se mais com manutenção e o mercado dispõe de novas "máquinas" que conseguem produzir mais em um tempo menor.

Pelo que foi dito sobre as exigências do mercado de trabalho, percebe-se que os critérios para a contratação têm ficado cada vez mais rígidos e impessoais. Se o desempregado não atende a uma das exigências da empresa (escolaridade, experiência profissional ou idade), ele é simplesmente cortado do processo seletivo, independentemente das suas capacidades individuais. Ou seja, pelo alto número de candidatos para cada vaga disponível e pelas exigências do mercado de trabalho globalizado, não há mais espaço para um relacionamento um pouco mais próximo entre contratante e contratado, em que a empresa poderia analisar cada caso individualmente, avaliando de forma mais criteriosa seus candidatos. Conforme foi visto nas "Estratégias de Sobrevivência e Recolocação", o uso atual do curriculum vitae nas estratégias atuais permite uma extrema distância entre candidato e empresa: num primeiro momento não há mais necessidade de contato pessoal entre o selecionador da empresa e o desempregado. A primeira etapa da seleção acontece pelo currículo, obedecendo-se rigidamente aos critérios adotados pela empresa para o "perfil" do candidato. 
Essa rigidez nas exigências do mercado de trabalho também está relacionada a questões práticas para os selecionadores das empresas: como o número de candidatos para cada vaga é muito alto, estabelecem-se critérios de escolha rígidos e bem definidos, o que permite diminuir o universo dos possíveis concorrentes para a seleção. Por exemplo: se uma empresa quiser contratar uma faxineira, pode colocar como um critério de escolha que a pessoa tenha o $1^{\circ}$ grau completo. Embora uma faxineira não precise deste grau de escolaridade para exercer a sua função, este critério para seleção diminui consideravelmente o número de candidatos.

Outra questão sobre a qual os entrevistados se ativeram foi com relação a comparações entre o estado atual e períodos anteriores de desemprego. Este assunto está diretamente relacionado ao confronto entre as estratégias de recolocação no mercado de trabalho usadas hoje em dia e em tempos passados, como já foi discutido, e aponta na mesma direção: há atualmente um agravamento no mercado de trabalho, que o torna mais exigente e menos recompensador. Tal situação acaba prejudicando as estratégias de recolocação, tornando-as ineficazes na maioria das vezes:

...antigamente, quando eu cheguei em São Paulo, logo eu fui conseguindo um trabalho... era muito mais fácil conseguir emprego. Os "carteiras-brancas" conseguiam emprego mais fácil. Agora... agora é mais difícil. (mulher, 24 anos, operacional).

Este tipo de observação foi comum ao discurso de todos os entrevistados, fossem trabalhadores operacionais ou não operacionais, demonstrando que a piora no problema do desemprego pode ser sentido em vários níveis sociais e não é um fenômeno isolado que poderia estar afetando apenas alguns segmentos da classe trabalhadora. Além disso, pelo que se percebe na última fala apresentada, o recrudescimento do mercado de trabalho tem tornado a busca do primeiro emprego de jovens trabalhadores cada dia mais difícil, já que não possuem nenhuma experiência profissional.

\section{Representações de Emprego:}

Com este tema pretendeu-se identificar as diferentes maneiras pelas quais os trabalhadores entrevistados caracterizaram as atividades profissionais que exerceram e, em especial, como definiram o que era "emprego". Acrescenta-se a esta questão uma discussão a respeito das considerações dos trabalhadores entrevistados sobre seu primeiro emprego, uma vez que foi recorrente a citação do primeiro emprego como aquele registrado na carteira profissional.

Tanto profissionais de nível operacional quanto não operacional fizeram uma distinção entre "emprego" e "bico". O principal critério utilizado para diferenciá-los relaciona-se à carteira de trabalho: "emprego" constitui-se em atividade registrada, enquanto "bicos" (não importando qual fosse) são atividades que não possuem registro em carteira. O tempo de exercício da atividade, bem como sua finalidade, também foram utilizados como critérios de diferenciação entre "emprego" e "bico". Para a maioria dos entrevistados a finalidade do "bico" era socorrer o trabalhador em uma situação financeira muito difícil, enquanto não conseguia um "emprego":

É só prá pegar um troco, prá não ficar assim... zero (homem, 32 anos, operacional).

O "bico" configurava-se, principalmente, como estratégia de sobrevivência e não tanto como uma estratégia de recolocação no mercado, visto que o objetivo da 
maioria dos trabalhadores (especialmente os operacionais) era voltar ao mercado de trabalho formal, saindo assim da condição instável e provisória do "bico". Embora houvesse trabalhadores que considerassem trabalhos não registrados como "emprego", acabavam reconhecendo que os "bicos" não são levados em consideração como prova de experiência profissional. Apenas as atividades registradas na carteira de trabalho serviam para comprovação, como já foi discutido no item "Representações do Mercado de Trabalho".

Um outro tipo de atividade profissional citada por um dos entrevistados foi o chamado "emprego temporário", que se apresentou como um meio termo entre o "emprego" e o "bico": possui registro, como o "emprego" (ainda que na maioria das vezes o registro fosse relegado pela empresa), e é um trabalho de curta duração, como o "bico" (com um tempo pré-determinado e que poderia ser prorrogado pela assinatura de outro contrato). Um dos entrevistados disse já ter passado, nos últimos 4 anos, por mais de 20 trabalhos deste tipo:

E desses 20, mais de 6 não registraram, nem fazia contrato, era só assim, acordo de palavra. (mulher, 33 anos, não operacional).

Embora a maior parte dos entrevistados não tenha feito uso deste "emprego temporário", sua existência no contexto social pode indicar uma maior aproximação entre a economia formal e informal, o que se tem verificado no grande contingente de trabalhadores que tem se deslocado do setor formal para o informal devido ao agravamento do desemprego. Além disso, mostra como as relações trabalhistas tem-se tornado cada vez mais frágeis e instáveis com a tão propalada flexibilização das relações de trabalho.

Embora o registro profissional seja um critério importante no conceito de “emprego", ele indica, na maioria das vezes, um cargo diferente da função que é realmente exercida pelo trabalhador:

...eles tão exigindo muito prá pagar muito pouco. Não que eu esteja reclamando, cê entendeu? Eles exigem demais. Eles querem que a pessoa faça dois, três, quatro, cinco funções... suponha, eu sou secretária, eu vou arrumar emprego e eles me contratam como auxiliar administrativo. Suponhamos. Mas de repente, se eu bobear, eu tô fazendo recepção, tô no administrativo, tô sendo secretária... cê faz tudo isso... e cê não pode se queixar. E cê tem consciência de que tem mais gente esperando sua vaga e se você bobear... (mulher, 40 anos, não operacional).

Este acúmulo de funções tem relação com o perfil profissional exigido do trabalhador num mercado globalizado: ele não pode ter apenas uma habilidade específica, mas deve ser versado em várias capacidades para exercer diferentes funções. Todavia, conforme depoimento citado acima, o acúmulo de funções não se tornou um enriquecimento para os trabalhadores. Pelo contrário, proporcionou um acúmulo de deveres nem sempre devidamente recompensado no salário e no registro profissional. Esta diversificação de funções exercidas que caracteriza atualmente o "emprego" e que não consta da carteira de trabalho relaciona-se com as exigências do mercado (discutidas no item "Representações do Mercado de Trabalho"), em especial com a necessidade de qualificação/escolaridade (na forma de várias capacidades) e, obviamente, com o requerimento do registro em carteira (como prova da experiência adquirida).

Relacionado ao agravamento das dificuldades de inserção no mercado de trabalho nos dias de hoje, os entrevistados fizeram referências nostálgicas aos seus 
primeiros empregos, numa época em que, segundo consideram, era muito mais fácil conseguir trabalho, pois o mercado não se apresentava tão exigente como nos dias atuais. Geralmente os entrevistados consideravam como sendo o seu primeiro emprego aquele registrado na carteira de trabalho, independentemente de já terem trabalhado na roça ou em outros locais que não constavam na carteira. Alguns começaram a exercer alguma atividade profissional (muitas vezes sem registro) em torno dos treze ou quatorze anos, em funções que não exigiam muita qualificação (office-boy, empregada doméstica, lavrador em uma agricultura de subsistência etc.):

O meu primeiro emprego, que eu considero mesmo, é esse que está registrado na carteira, né. (mulher, 24 anos, operacional).

Independentemente do sexo ou da categoria de trabalho dos entrevistados, todos relataram o uso da rede de relações interpessoais como o meio adotado para conseguirem os seus primeiros empregos, isto é, o primeiro trabalho registrado foi obtido através de informação e/ou indicação de familiares ou conhecidos:

Meu irmão arrumou prá eu trabalhar na Sociedade Hípica Paulista, né, que fica no Brooklin. Ele conhecia um gerente de lá e me pegou. (homem, 34 anos, operacional).

Conseguiu esse bico [auxiliar de arquivista] devido ao meu pai, que trabalhava na [empresa..], ele tinha 14 anos. (homem, 33 anos, não operacional).

Eu consegui o emprego no colégio porque o meu irmão trabalhava lá... Eu fiz uns testes, passei e fui admitida. (mulher, 26 anos, operacional).

Conforme foi discutido no item "Estratégias de Sobrevivência e Recolocação no Mercado", a rede teve e ainda tem uma grande importância na busca de um emprego, tanto em uma nova recolocação como no primeiro emprego, ainda que a sua eficiência tenha sido muito maior no passado, quando a problemática do desemprego não se apresentava tão grave como hoje em dia e o mercado de trabalho era mais flexível. Ela ainda mantém o status de uma das principais estratégias de recolocação.

Do que foi dito até o momento, pode-se concluir a fundamental importância da carteira profissional para a vida do trabalhador. Ela é o critério que separa "emprego" de "bico" e, como tal, delimita o que foi o primeiro emprego de cada um. Acrescente-se a isto seu importante papel na definição profissional: quando perguntado aos entrevistados quais eram as suas profissões, estes referiam-se literalmente ao nome de um dos cargos em que foram registrados ("operador de máquina" ou "auxiliar de contas a pagar”, por exemplo), dando preferência à última atividade que constava em suas carteiras de trabalho. É importante lembrar também que o registro profissional constitui-se na única prova reconhecida da experiência do trabalhador.

A carteira de trabalho tem outro papel importante na reinserção no mercado: alguns entrevistados fizeram menção ao fato de se "sujar a carteira", ou seja, aceitar um novo emprego com salário e/ou cargo inferior a registros anteriores. Tal fato possui uma conotação negativa, segundo os trabalhadores: pode prejudicar a procura e a recolocação em futuros empregos, pois constitui-se prova de que a pessoa "não tem muito critério" e aceita qualquer tipo de trabalho. Estabelece-se uma situação paradoxal: um desempregado pode até ter uma oferta de emprego, porém, se ela for "sujar" a carteira, ele tende a não aceitá-la, porque isto dificultaria uma futura recolocação profissional. Recusando o emprego, continuará desempregado, mas aceitá- 
lo, por outro lado, pode implicar em uma dificuldade para conseguir um emprego melhor futuramente.

Deste modo, a própria definição de "emprego" e, de forma mais ampla, a identidade profissional dos trabalhadores estão diretamente relacionadas à carteira de trabalho. Ela não é apenas um documento que assegura os direitos trabalhistas, mas um símbolo da história profissional do trabalhador e de sua relação com o mercado de trabalho.

\section{Explicação Sobre o Próprio Desemprego:}

Dentro deste tema pretendeu-se enfocar o modo pelo qual o trabalhador explica o seu próprio desemprego. O objetivo inicial era verificar se os entrevistados apontariam características pessoais ou das empresas (e, em sentido mais amplo, do próprio mercado) como responsáveis pelo seu desemprego. No entanto, a análise das entrevistas revelou que tal distinção é muito complexa. Embora todos os entrevistados responsabilizem a situação do mercado (ver "Representações do Mercado de Trabalho") pelo próprio desemprego, isto não deixa de ter influências na pessoa, que acaba sentindo-se fracassada e impotente por não conseguir uma recolocação.

A frase seguinte é exemplar por mostrar como confunde-se no discurso do trabalhador a responsabilidade do mercado e da própria pessoa no desemprego, juntamente com a sensação de fracasso:

É difícil de entrar por causa da minha idade, não é que eu sou barrada, eu sou descartada, eu sou totalmente desfeita. Porque se não tem de 18 a 22 anos, de 22 a 28 no máximo, se não tem um bom curso de computação... não tenho computação... não tem o mínimo de inglês... ou a mínima fluência de inglês, ou você... não se aceita os horários ou... às vezes se abrem bastante vagas para recepcionistas, mas com essas condições. E às vezes não exige tanto, mas aí não são tantas vagas. (mulher, 33 anos, não operacional).

Além da sensação de fracasso pessoal, era comum a indagação sobre o motivo de não se conseguir um emprego. Explicando: o atual estado do mercado provoca situações em que mesmo trabalhadores muito qualificados e com alto potencial não conseguem recolocação. Surge então a dúvida: "se sou tão qualificado, por que não consigo emprego?". O trabalhador vive sua situação sem compreender totalmente o que está acontecendo:

Concursos eu fiz de montão. Eu fiz concurso prá companhia telefônica, peguei classificação 10. Mas com essa baixaria que andaram aprontando em serviço público... chamaram até a classificação... acho que número 3. Fiz na Eletropaulo... passei. Fiz na Polícia Civil... fiz na Prefeitura... passei. E não chamam! (mulher, 40 anos, não operacional).

Assim, não importa que o mercado seja classificado como o principal responsável pelo desemprego. Este é sentido como um fracasso pessoal que, em última análise, fica sem uma explicação convincente para o trabalhador. 


\section{Perspectivas de Futuro:}

Este tema refere-se às expectativas dos entrevistados em relação a seu próprio futuro, sendo a maioria das respostas relacionadas, direta ou indiretamente, ao campo do trabalho (até pelo próprio foco e interesse da pesquisa).

Havia, na maioria das falas dos entrevistados, um misto de desilusão e esperança: a situação é considerada muito difícil (ver "Representações do Mercado de Trabalho"), não havendo muitas alternativas disponíveis. Ao trabalhador resta torcer para que as coisas melhorem. Este fato assumiu um colorido especial no discurso dos entrevistados migrantes de outros estados brasileiros: embora a vida em São Paulo fosse considerada muito ruim, a possibilidade de se arrumar um emprego aqui era melhor do que em suas terras natais, onde a maior opção de trabalho era a roça. Ao que parece, São Paulo ainda é considerada a "terra das oportunidades", onde se vai conseguir "vencer na vida". O grupo das mulheres operacionais foi o único a manifestar mais claramente um desejo de, no futuro, retornar definitivamente à terra natal. Neste caso, as mulheres permaneciam em São Paulo com o objetivo de guardar algum dinheiro:

Aqui em São Paulo a vida é muito corrida, mas eu falo, não adianta nada voltar agora sem nenhum dinheiro. (mulher, 39 anos, operacional).

Ao lado da desilusão e da esperança de que o mercado melhore, também há muitas expectativas pessimistas - e algumas poucas otimistas - no que diz respeito ao futuro pessoal. Dentre as expectativas positivas, duas se destacam. Em primeiro lugar, como não poderia deixar de ser, há uma esperança em se conseguir um bom emprego, definido basicamente como aquele que ofereça boas condições, entre elas, bons salários, benefícios etc. Em segundo lugar, existe uma expectativa de melhora através do estudo, o que não deixa de estar relacionado de alguma forma às exigências do mercado:

...agora se eu conseguir um emprego, agora, né... vou pensar em fazer o $1^{\circ}$ e o $2^{\underline{o}}$ grau, fazer no mínimo a 8ํㅗ série. (homem, 34 anos, operacional).

Essas esperanças pessoais de conseguir um bom emprego e um grau de escolaridade maior não deixam de representar uma esperança de melhora financeira e/ou profissional, mas, principalmente, indicam um desejo de progresso pessoal.

Não se pode afirmar com certeza se estas expectativas positivas, tanto em relação ao mercado como para a vida pessoal, baseariam-se em dados reais e indicações concretas ou seriam uma espécie de reação contrária à desilusão e falta de esperança que foram caracterizadas nas "Estratégias de Sobrevivência e Recolocação no Mercado" e nas "Representações do Mercado de Trabalho".

\section{Rompimento do Vínculo de Trabalho:}

Através deste tema procurou-se conhecer os diversos motivos que levaram ao rompimento dos vínculos de trabalho dos entrevistados em seus diversos empregos, colocando-os no grande contingente de trabalhadores desempregados.

O rompimento do vínculo de trabalho (dispensa) pode ser compreendido em três situações principais: quando a responsabilidade pelo rompimento é da empresa (sem influência direta do funcionário); quando a responsabilidade é totalmente do funcionário (sem influência direta da empresa); quando a responsabilidade está na empresa, mas quem toma a decisão de sair é o funcionário. 
Dentre os diversos motivos que foram observados durante as entrevistas, percebeu-se que o rompimento causado exclusivamente pela empresa é o mais freqüente entre todos. Entre eles destacou-se o corte de custos/pessoal como a maior justificativa para a dispensa de trabalhadores (isto quando os funcionários eram avisados do motivo de sua demissão). Houve situações em que o funcionário não desejava sair, porém, ao pedir os seus direitos legais, acabava sendo demitido pela empresa:

É, trabalhei quatro anos, também não fui registrada... quando fui falar em registro me mandaram embora. (mulher, 32 anos, operacional).

Esse processo de demissão de funcionários visando o "enxugamento" da empresa é vivido pelos trabalhadores de maneira traumática e desnorteante: vários dos entrevistados descreveram a situação de estarem trabalhando normalmente, quando, "num belo dia" (geralmente às segundas-feiras), eram avisados de que deveriam passar no Departamento de Pessoal e lá recebiam a informação de que haviam sido demitidos, sem que houvesse uma justificativa mais palpável. Como os trabalhadores não têm controle sobre o momento em que serão mandados embora e nem participam deste processo decisório (que é vivenciado de uma maneira arbitrária), muitas indagações ficam "suspensas no ar", sem uma explicação que consiga dar-lhes sentido: "...por que fui mandado embora se estava fazendo o meu serviço direitinho?"; "...por que eu fui demitido e aquele outro não?".

O rompimento causado exclusivamente pelo funcionário é um dos menos freqüentes hoje em dia e só parece ocorrer em situações extremas. Uma destas situações relaciona-se à condição da mulher em nossa sociedade: quando torna-se mãe ou algum parente muito próximo adoece, ela se vê obrigada a deixar o emprego:

Saí porque minha mãe adoeceu, e não tinha quem cuidasse dela. (mulher, 32 anos, operacional).

O funcionário tomava a decisão de sair do emprego apenas quando tinha efetivamente garantido um novo emprego que fosse melhor. Caso contrário, isto não acontecia.

As duas situações anteriores são condizentes com o que se pode encontrar atualmente. Raramente os trabalhadores pedem demissão, pois a garantia de se obter outro emprego é muito reduzida. Enquanto isso, devido a processos de globalização e desenvolvimento tecnológico, as empresas têm "enxugado" o número de seus funcionários, como forma de contenção de custos e de se ajustar ao perfil competitivo atual, segundo mostra a introdução deste trabalho.

A situação típica em que a causa da quebra de contrato está na empresa, mas quem toma a decisão efetiva de sair é o funcionário, parece acontecer quando o empregador faz promessas explícitas (aumento de salário ou promoção, na maioria das vezes) e não chega a cumpri-las, levando o empregado a pedir demissão. Este tipo de situação, bastante conflitante, é mais um dos reflexos da desarmonia nas relações de trabalho, visto que as empresas vêem-se no direito de fazerem promessas e não cumprilas, tratando o trabalhador como um mero objeto de seus interesses. Caso este exija o que lhe foi prometido, pode simplesmente ser mandado embora. 


\section{Conclusões}

Da mesma forma que na pesquisa realizada com empregadas domésticas e trabalhadores da construção civil (Lautier e Pereira, 1994), a rede de relações interpessoais constitui-se na principal estratégia adotada pelos desempregados para a sua recolocação profissional. Mas, muito mais que isso, a rede aparece também como uma das estratégias de sobrevivência mais utilizadas e demonstra ter influência em outros campos.

Como estratégia de sobrevivência, a rede aparece na forma de troca de favores: quando uma pessoa está desempregada e necessita de ajuda para sobreviver, pede ou recebe favores dos seus parentes e amigos mais próximos, favores estes que serão cobrados ou retribuídos quando a pessoa estiver novamente empregada e seus conhecidos é que estiverem sem trabalho. No núcleo familiar, por exemplo, conforme a situação em que se encontrem seus membros, há uma ajuda mútua até que a situação se altere.

Talvez este seja o princípio do uso da rede como estratégia de sobrevivência: embora alguns de seus membros estejam desempregados, a rede como um todo consegue manter-se, pois as trocas de favores garantem que alguns de seus participantes cuidem da sobrevivência de outras pessoas (mesmo porque quem está empregado hoje pode não estar amanhã).

A rede de relações interpessoais demonstra ter influência também em outros tipos de estratégias adotadas. Da mesma forma que Lautier e Pereira (1994) concluíram que as pessoas conseguiam empregos mais através de informações personalizadas do que pela resposta de um mercado anônimo e impessoal, na atual pesquisa observou-se que, quando as pessoas pensavam em se tornar autônomos, as idéias de possíveis negócios advinham de familiares ou conhecidos, muito mais do que por uma análise da viabilidade do mercado. Enquanto um homem não operacional planejava montar um negócio particular (seja uma micro empresa, seja um pequeno comércio) para progredir financeiramente, suas idéias eram influenciadas pelas sugestões de pessoas próximas ou de conhecidos que trilharam o mesmo caminho. Um exemplo pode ser esclarecedor: um homem não operacional que trabalhava na área de contabilidade de uma empresa planejava tornar-se caminhoneiro ou motorista particular, muito mais pelo exemplo de alguns conhecidos que entraram neste ramo e por um desejo pessoal do que propriamente por uma análise do mercado, ou pela sua capacitação, ou experiência na área. $\mathrm{O}$ mesmo acontecia com os trabalhadores operacionais: quando estes pensavam em montar uma pequena barraquinha para sobreviver enquanto não conseguiam emprego, o tipo de comércio a ser realizado na barraquinha era determinado pelo exemplo de conhecidos que abriram o mesmo negócio. Uma pessoa cujos conhecidos montaram barraquinhas de cachorro quente, tinha a tendência de montar o mesmo tipo de atividade.

Afora os negócios próprios (microempresa ou "barraquinha"), outro fato deve ser acrescentado às alternativas utilizadas quando o acesso ao mercado de trabalho formal está impedido: o uso dos bicos. Ao que parece, estes também estão, de alguma forma, regulados pelas redes de relações pessoais: quando um trabalhador operacional fazia um bico de pintor, geralmente era na casa de conhecidos, ou como forma de conseguir dinheiro, ou como pagamento por dívidas e/ou favores passados. E mesmo quando o serviço era executado na casa ou escritório de desconhecidos, o acerto era através da rede. Um exemplo típico é do desempregado que vai fazer um bico (como pintor ou eletricista) na casa do chefe de um conhecido seu que o indicou para o trabalho. 
Desta forma, a influência e o poder da rede de relações interpessoais dão-se através de três vetores no caso dos desempregados: a rede é a principal estratégia das pessoas que estão tentando voltar ao mercado de trabalho formal; é ela que condiciona as escolhas das pessoas que estão desenvolvendo alternativas ao mercado (negócios próprios ou bicos); a rede faz parte das estratégias das pessoas que não conseguem se manter, seja porque não há possibilidades de voltar ao mercado, seja porque não podem desenvolver alternativas para se sustentarem.

Convém lembrar que, apesar de este poder e influência sejam notórios, sua forma de atuação é muito complexa. Um único trabalhador está inserido em diversas redes que se entrecruzam e atuam de diversas maneiras sobre as suas estratégias: a mesma pessoa faz parte de redes aglutinadas pela religião, partidos e ideais políticos, pela comunidade onde mora, pelos parentes que estão distantes (geralmente em seu estado de origem), pela categoria profissional a que pertence etc. Esta pesquisa teve acesso a um pequeno recorte desta complexidade, pois preocupou-se apenas com os desempregados que habitam uma parte da Grande São Paulo, desempregados estes que fazem partes das mais diversas e complicadas redes de relações interpessoais. A constatação do poder da rede é evidente, muito embora, para se entender os seus diversos mecanismos, faz-se necessário um aprofundamento nas suas diversas instâncias e entrecruzamentos. Uma das perguntas que se configura é se haveria alguma "hierarquia" nas diversas redes de que o desempregado faz parte: se, por exemplo, a rede formada pelo culto religioso seria mais importante que outras redes na determinação das estratégias dos desempregados.

No entanto, se o uso da rede de relações interpessoais é uma das mais importantes estratégias de recolocação, ela não deixa de sofrer modificações decorrentes das mudanças no mercado de trabalho e nas relações trabalhistas. Alguns dados desta pesquisa podem ajudar a pensar neste assunto. Conforme constatado, a eficácia da rede não é mais a mesma que em tempos anteriores. Se a maioria dos entrevistados conseguiu os seus primeiros empregos através da participação da rede, esta não demonstra levar aos mesmos resultados hoje em dia, devido ao recrudescimento do mercado de trabalho e às mudanças no perfil do trabalhador. Embora as estratégias usadas atualmente sejam as mesmas do passado (jornais, agências de emprego, placas etc.), os desempregados têm que recorrer a um número maior delas como forma de tentar aumentar as suas possibilidades de reinserção, não podendo permanecer em apenas um tipo de estratégia. É com esta idéia que se deve entender o aumento da procura de empregos através do currículo, de acordo com o que foi constatado nesta pesquisa. $\mathrm{O}$ uso do curriculum vitae, que se tornou um importante auxiliar nas estratégias de recolocação atuais, revela como as concepções sobre o trabalhador moderno, sobre a busca de emprego e sobre o mercado de trabalho têm se alterado ultimamente. Talvez o currículo seja um dos melhores indicadores de todas estas mudanças no mundo do trabalho e nas relações trabalhistas. Como o número de vagas tem diminuído, ao mesmo tempo em que aumentam os concorrentes, o uso do currículo é uma forma de, teoricamente, aumentarse as possibilidades de reinserção. Não há mais a necessidade de ir pessoalmente em busca da vaga. Se antes, em um dia, o trabalhador podia visitar, no máximo, duas ou três empresas para preencher algumas fichas, agora ele pode contatar um número muito maior de empresas em um espaço reduzido de tempo, através do currículo. Por outro lado, o maior uso do currículo pelos desempregados mostra como a busca de emprego tornou-se bastante "impessoal". As relações entre concorrente e contratante ficaram mais distantes: não há mais uma escolha de pessoas, mas uma escolha de currículos, visto que a maior parte dos processos seletivos realizados pelas empresas ocorre, única e exclusivamente, através deles, sem a presença do trabalhador. Por meio deste mesmo processo, candidatos que não possuem alguns dos requisitos pedidos para a vaga (idade, experiência ou qualquer outro atributo) são cortados do processo seletivo, não 
importando se seriam adequados ao emprego. Este movimento todo pode ser verificado nos jornais que, ultimamente, tem sessões especiais para análise, comentário e "dicas" de como fazer um bom currículo.

Estas mudanças nas estratégias de recolocação acompanham, como não poderia deixar de ser, as próprias modificações objetivas no mercado (redução dos postos de trabalho, fragilização das relações trabalhistas etc.) e também as representações sociais envolvidas. Sendo as representações sociais uma forma de conhecimento prático que guia as ações no cotidiano, mudanças no mercado de trabalho são, necessariamente, acompanhadas de mudanças nas representações sociais, gerando modificações nas estratégias utilizadas pelos desempregados. Assim, o saudosismo encontrado nos discursos dos desempregados, relembrando tempos em que era mais fácil conseguir uma vaga, aponta para uma situação que não existe mais.

As representações sociais sobre o mercado de trabalho mostram como este tem se alterado nos últimos tempos. Justamente por tratarem-se de desempregados, as suas representações falam sobre as exigências e a dificuldade de participarem deste mesmo mercado de trabalho na era da globalização. Se, conforme Mattoso (1994), “...esta reestruturação do capitalismo também apontou para um novo trabalhador, mais escolarizado, participativo e polivalente, podendo inclusive ser portador de uma revalorização da ética e da utopia do trabalho..." (p. 14), quando vista pela ótica dos desempregados a história é outra. Este novo modelo tornou-se a marca das exigências e da desvalorização do trabalho: a qualificação/escolaridade e a multiplicidade de funções não são encaradas como ganhos pessoais, mas como obrigação imposta e, o que é pior, pouco remunerada. Desta forma, o novo modelo não é uma revalorização do trabalhador como um ser humano, mas apenas como "mercadoria" de produção. Não por menos, uma das principais exigências do mercado de trabalho diz respeito à idade: deve-se aproveitar o trabalhador no auge da sua capacidade produtiva (até os 30 ou 40 anos), substituindo-o quando não apresentar mais esta capacidade. Assim, as representações do mercado de trabalho apontam para uma igualdade entre mercadoria e trabalho na lógica do mundo globalizado: maior qualidade pelos menores preços (no caso do trabalhador, salários). Não por acaso, o curriculum vitae, conforme já comentado, mais parece um "rótulo" de embalagem do que propriamente o levantamento do histórico profissional do trabalhador.

Além das representações sociais sobre o mercado de trabalho, as representações sobre emprego são importantes para se entender as estratégias de recolocação. Fora o fato óbvio de que estas estratégias são arquitetadas para conseguir-se um novo emprego, é necessário entender que não é qualquer atividade que é considerada como emprego. De acordo com o que foi constatado nesta pesquisa, "emprego" é a atividade registrada na carteira de trabalho que, potencialmente, tem uma certa estabilidade de duração, enquanto "bico" seria a atividade não registrada, de pouca duração e que geralmente tem a finalidade de socorrer financeiramente o trabalhador até conseguir um novo emprego. É bom lembrar que estas representações só adquirem sentido dentro do contexto em que se inserem: a atividade profissional socialmente valorizada em um grande centro urbano e industrial como São Paulo é o emprego. Este carrega, hipoteticamente, a possibilidade de ascensão social e financeira aos trabalhadores das classes mais baixas. Os trabalhadores desenvolvem estratégias para conseguir emprego e, quando estas se tornam ineficazes, desenvolvem outros tipos de estratégias para a sua sobrevivência (como os bicos). Caso a pesquisa fosse feita em uma cidade eminentemente rural, a distinção entre emprego e bico teria possivelmente outros parâmetros, ou ainda, apareceriam outros tipos de categorias.

Apesar de a distinção entre "emprego" e "bico" aparecer de uma maneira mais ou menos clara, o processo de globalização tem aproximado essas categorias, que podem 
tornar-se indiferenciadas ou até mesmo extintas com o passar do tempo. Com a dificuldade de reinserção no mercado formal de trabalho, cada vez mais um grande contingente de pessoas tem passado para a economia informal, através de bicos ou pequenos comércios (as ditas "barraquinhas"). Mais do que isso, a categoria "emprego temporário" mostra como as economias formais e informais têm se aproximado. O emprego temporário possui características comuns ao "emprego" e ao "bico", ficando a um meio termo entre ambos: é uma atividade registrada em carteira (como um "emprego"), mas tem um tempo curto de duração e serve como um socorro financeiro até a pessoa conseguir um emprego definitivo (como um "bico").

Esta aproximação entre "emprego" e "bico" também reflete um enfraquecimento nas relações trabalhistas. Embora, teoricamente, o emprego temporário ofereça os mesmos direitos e benefícios de um emprego comum, a sua existência mostra uma alteração nos vínculos entre as empresas e os trabalhadores. A partir do momento em que um trabalhador pode estar em uma determinada empresa em um mês, em outra no mês seguinte e talvez em outra no futuro (conforme for deslocado entre vários empregos temporários), a identidade e a ligação da pessoa com a empresa (e com o seu trabalho) ficam prejudicadas, visto não mais haver vínculos estáveis entre ambos. No emprego, a pessoa, teoricamente, tem a perspectiva de um tempo de permanência relativamente estável (fora situações específicas, como, por exemplo, falência iminente ou previsão de cortes de pessoal), o que não acontece no emprego temporário, pois, findo o tempo de contrato, ela é dispensada.

Nestas representações sobre emprego, um elemento ganha um destaque muito especial: a carteira de trabalho. Ela não apenas é um dos critérios para diferenciar "emprego" de "bico", mas acaba tendo uma participação fundamental nas estratégias adotadas pelos desempregados, visto ser um representante objetivo da identidade profissional dos trabalhadores: quando interrogados sobre qual era sua profissão, eles respondiam com o nome da última função exercida, esta registrada na carteira de trabalho ("operador de máquina", "auxiliar de produção" etc.). A identidade profissional, construída, entre outras coisas, pelo histórico de trabalho da pessoa, vai influenciar em suas estratégias, principalmente no que se refere à função procurada no novo emprego. Foi o constatado na diferença entre trabalhadores operacionais e não operacionais: enquanto estes têm uma procura um pouco mais específica, aceitando funções correlatas e próximas das exercidas anteriormente, os trabalhadores operacionais tendem a aceitar qualquer tipo de emprego para garantir a sua sobrevivência. Um exemplo pode ser esclarecedor: uma telefonista (cuja profissão é considerada não operacional, conforme classificação do Sinesp) procurava, principalmente, vagas de telefonista, porém não descartava ofertas para recepcionistas ou atendentes de telemarketing (trabalhos próximos ou muito semelhantes à função de sua preferência). Já um auxiliar de produção (uma profissão operacional) também optava por estas vagas, podendo, contudo, aceitar trabalhos de empacotador, faxineiro ou servente de pedreiro (funções diferentes da preferência, mas que têm em comum o fato de envolverem trabalho muito repetitivo e esforço físico intenso).

A carteira profissional, além disso, marca a entrada da pessoa no mundo do trabalho, pelo menos em um grande centro urbano como São Paulo. As pessoas tendem a denominar o primeiro registro profissional como sendo o seu primeiro emprego, independentemente de terem executado outros tipos de atividade remuneradas ou não (como agricultura de subsistência, carreto em feiras etc.). Isto dá um pouco da medida de como o emprego (a atividade profissional registrada) tem uma importância muito grande para as pessoas entrevistadas. Não por acaso, a esperança delas está em conseguir um "bom emprego", caracterizado como aquele que oferece boa remuneração e benefícios. O emprego é a forma pela qual se consegue melhora financeira, progresso 
pessoal e se conquista uma boa imagem e reputação diante de si, dos familiares e da comunidade. É desta forma que se deve entender determinadas estratégias que, em um primeiro exame, poderiam parecer muito estranhas: o caso da expressão "sujar a carteira" usada pelos entrevistados é um bom exemplo. Esta situação ocorre quando um trabalhador aceita um novo emprego por um salário ou cargo inferior ao último registrado em carteira. Isto não é visto com bons olhos pelos empregadores e nem pelos próprios trabalhadores, uma vez que "sujar a carteira" tem a conotação de que a pessoa aceitou ser rebaixada. Desta forma, surgem situações paradoxais: um desempregado, tendo uma oferta de emprego diante de si, tende a não aceitá-la, se isto implicar em "sujar a carteira". Ele toma esta atitude por duas razões principais: em primeiro lugar porque "sujar a carteira" poderá implicar em futuras dificuldades em encontrar um novo emprego; além disso, as marcas vão ficar na sua própria carteira de trabalho e "sujá-la" representa um fracasso pessoal, pois quebra a imagem de sucesso profissional. Com o passar dos anos isto pode tornar-se uma situação muito complicada, pois, com a tendência do mercado a abaixar cada vez mais os salários, não haverá como evitar que o trabalhador "suje a carteira".

Aliás, o fracasso é um problema difícil com que o desempregado tem que lidar. Embora "saiba" que o problema está no mercado de trabalho que anda muito exigente e concorrido, que há várias outras pessoas desempregadas, ele não deixa de sentir o seu desemprego como um fracasso pessoal. Diante deste quadro, surgem situações muito complicadas para as quais o próprio trabalhador não consegue uma explicação. A atual situação do mercado de trabalho faz com que pessoas muito qualificadas não consigam empregos, o que não deixa de ser contraditório, diante das exigências que este mesmo mercado faz aos seus concorrentes. Desta forma, como explicar o próprio desemprego para aquela pessoa que corresponde ao novo modelo de trabalhador globalizado e que, portanto, deveria estar participando do mercado? O desemprego é produzido estruturalmente, mas se manifesta através da vida cotidiana das pessoas.

Para finalizar este trabalho, faz-se necessário pensar um pouco de que forma ele poderia contribuir na busca de soluções para o desemprego. Pelo que foi discutido, a intervenção sobre este problema deve acontecer em dois níveis que necessariamente não se excluem: em primeiro lugar, precisa-se garantir formas de sobrevivência para os desempregados, já que estes necessitam resolver um problema imediato de conseguir dinheiro para as suas necessidades básicas de alimentação e moradia. Embora a rede de relações interpessoais seja uma das formas usadas para a sobrevivência, à medida que o número de desempregados for aumentando, a eficácia deste sistema pode ficar comprometida, pois aqueles que estiverem empregados não conseguirão ajudar economicamente um contingente muito grande de pessoas sem trabalho.

Em segundo lugar, conforme apontado por Mattoso (1994), o problema não se resume, única e exclusivamente, à diminuição do número de vagas no mercado: há uma fragmentação e fragilização do mundo do trabalho e nas suas relações. Talvez muito mais que isso, a própria cidadania das pessoas encontra-se ameaçada, visto não conseguirem participar "economicamente" da sociedade. Desta forma, muito mais que pensar na abertura de vagas e na qualificação dos trabalhadores, deve-se discutir sobre a reinserção social dos desempregados (e não apenas no mercado de trabalho), acompanhada da construção de mecanismos institucionais para uma melhor distribuição de renda.

Um dos possíveis caminhos para a solução destes problemas poderia ser a criação de outros reguladores sobre o mercado de trabalho, não permitindo que este esteja abandonado, apenas e tão somente, à lógica do mundo globalizado. Conforme apontado por Lautier e Pereira (1994), sendo o mercado de trabalho regulado por um tripé formado pelo Mercado, Estado e Rede, faz-se necessário que estes dois últimos tenham 
força e poder suficientes para contrabalançar e atuar de forma mais racional sobre o mercado de trabalho. É o que, infelizmente, não acontece nos países de terceiro mundo: o poder público (como um dos representantes dos mecanismos institucionais de controle) não exerce o seu papel regulador neste tripé e, portanto, são justamente estes países que mais sofrem com o desemprego estrutural. A falta de fiscalização sobre condições de trabalho e o uso de crianças de forma escrava são apenas alguns dos reflexos deste importante problema gerado por um capitalismo sem controle e agravado com a globalização.

\section{Bibliografia}

Lautier, B. e Pereira, J. M. (1994). Representações sociais e construção do mercado de trabalho: empregadas domésticas e operários da construção civil na América Latina. Cadernos CRH, Salvador, 21: 125-151.

Mattoso, J.E.L. (1994). Trabalho sob Fogo Cruzado. São Paulo em Perspectiva, 8 (1): 13 21.

Spink, M.J.P. (1994). Desvendando as teorias implícitas: uma metodologia de análise das representações sociais. In: P. A. Guareschi e S. Jovchelovitch (orgs.) Textos em representações sociais, Petrópolis: Vozes. 4ํㅜ capítulo. 